DOI:10.17951/h.2020.54.1.31-40

\begin{tabular}{lcc}
\hline & A N N A L E S \\
UNIVERSITATIS MARIAE CURIE-SKŁODOWSKA \\
LUBLIN - POLONIA \\
SOL. LIV, 1 & SECTIO H \\
\hline
\end{tabular}

\title{
SYLWIA FRYDRYCH
}

sylwia.frydrych@sgh.waw.pl

SGH Warsaw School of Economics. Collegium of Management and Finance.

Institute of Risk and Financial Markets

162 Niepodległości Av., 02-554 Warsaw

ORCID ID: https://orcid.org/0000-0002-1215-49500

\section{The Delisting of a Company from the Warsaw Stock Exchange as a Result of the Cancellation of the Dematerialisation of Shares - Tender Offer Price vs. IPO Price}

Keywords: Warsaw Stock Exchange; dematerialisation of shares; public tender offer

JEL: G19; G20; G24

How to quote this paper: Frydrych, S. (2020). The Delisting of a Company from the Warsaw Stock Exchange as a Result of the Cancellation of the Dematerialisation of Shares - Tender Offer Price vs. IPO Price. Annales Universitatis Mariae Curie-Skłodowska, sectio H-Oeconomia, Vol. 54, No. 1.

\footnotetext{
Abstract

Theoretical background: The growth in the number of companies delisted from the Warsaw Stock Exchange (WSE), as a result of the cancellation of the dematerialisation of shares, has become a reason for considerations regarding the share price in tender offers addressed to shareholders who have held company securities since the Initial Public Offering (IPO).

Purpose of the article: The goal of this study was to evaluate whether the price in tender offers of the shares of companies which had finally been excluded from trading on the WSE as a result of the cancellation of the dematerialisation of shares would ensure a positive rate of return for shareholders who have held the shares since this company's debut on the regulated market of the WSE.

Research methods: Public tender offers, announced between 2012 and 2018 on the regulated market of the WSE have been analysed. The analysis covered prices of shares of new listings on the WSE and share prices in the tender offers of 213 companies, out of which 55 companies have been excluded from trading on the regulated market of the WSE as a result of the cancellation of the dematerialisation of shares.
} 
Main findings: The results of the research indicate that more than a half of the shareholders who have held the securities of companies in their portfolio since their debut, have suffered losses after companies have been excluded from trading on the WSE as a result of the cancellation of the dematerialisation of shares. Only $11 \%$ of the examined companies have generated more than double profit for investors compared with the issue price during their IPO. This research is one of the few studies on the Polish stock market to the best of the author's knowledge.

\section{Introduction}

In 2018, 465 companies were listed on the regulated market of the Warsaw Stock Exchange (WSE). A year before, this figure amounted to 482 companies, whereas in 2015 and 2016, a total of 487 companies were listed on the WSE. At the same time, 103 companies were delisted from the WSE between 2012 and 2018, including 55 entities as a direct result of the cancellation of the dematerialisation of shares. These data indicate that the number of companies listed on the WSE has decreased significantly in recent years. It is an important issue in the situation when more companies leave the stock exchange and the number of new listings is decreasing (Figure 1).

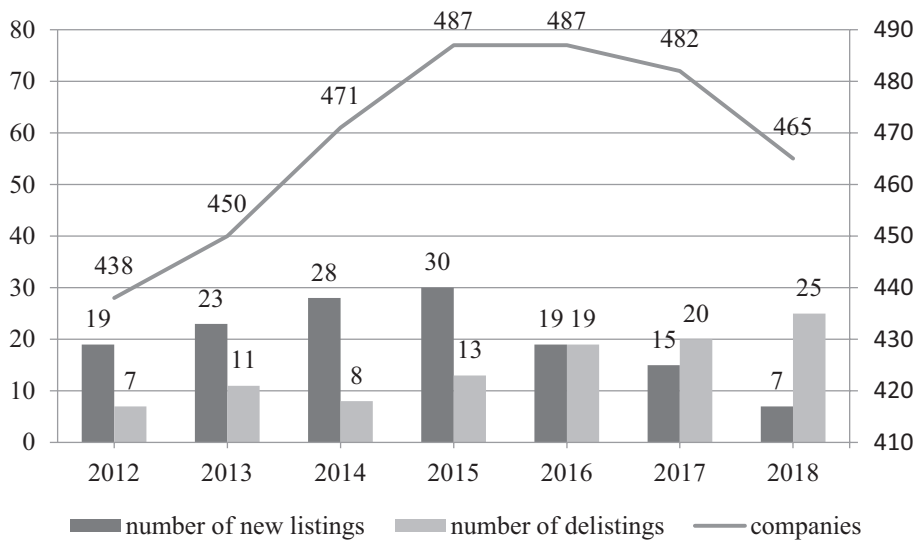

Figure 1. The total number of new listings, delistings and companies on the regulated market of the WSE

Source: Author's own study based on (Rocznik Giełdowy 1997-2008).

In view of the above, a question arises regarding prices in the tender offer presented by an entity acquiring shares. The requirement that the tender offer price should be a fair price stems both from the regulations of the Commercial Companies Code and general rules of the entire legal system. Now, there is a question of whether obtaining a fair price by an investor who acquired shares during the Initial Public Offering (IPO) allowed them to make a profit.

The goal of this study is to examine whether the share price announced within the tender offer, which ended in delisting of the company from the WSE as a result 
of the dematerialisation of shares, ensured a positive Return on Investment (ROI) for shareholders. The analysis was carried out based on the assumption that the shareholders have held their securities since the debut of the company on the public regulated market.

A period of analysis covers the companies which were delisted from the WSE's regulated market as a result of the cancellation of dematerialisation of shares in the period of 2012-2018. Transaction costs, paid dividends and the time value of money have not been taken into account during the analysis. In order to isolate a sample group, only companies for which the tender offer had resulted in delisting of shares from trading on WSE have been included in the analysis. Furthermore, the author examined the period of time during which a given company was listed on the regulated market of WSE, i.e. the period since the debut of the company until its delisting as a result of the cancellation of the dematerialisation of shares by means of a tender offer.

\section{The procedure of delisting a company through the dematerialisation of shares as a result of the tender offer}

Exclusion (withdrawal, delisting) of shares from public trading is the polar opposite process to a company's introduction to the stock exchange (the Initial Public Offering, IPO). Article 31 item 1 of the WSE Rules states the reasons which form the basis for delisting a financial instrument from trading (WSE Rules, Resolution No. 1/1110/2006 of the Warsaw Stock Exchange Supervisory Board dated 4 January 2006, as amended). These are:

- restricted transferability,

- at the request of the Financial Supervision Authority made in accordance with the Act 29 of 29 July 2005 on Trading in Financial Instruments (Journal of Law of 2005, no. 183 item 1538, as amended; hereinafter referred to as the Trading Act),

- if the instrument is no longer dematerialised; and

- if it is delisted from trading on the regulated market by a relevant supervisory authority.

The procedure for the cancellation of the dematerialisation of shares and their delisting from public trading on the organised market of the WSE is governed by Article 91 of the Act of 29 July 2005 on Public Offering, Conditions Governing the Introduction of Financial Instruments to Organised Trading and Public Companies (Journal of Law of 2019, item 623, that is of 22 February 2019; hereinafter referred to as the Act on Public Offering). When delisting a company from public trading, a Resolution of the general shareholders meeting is required, adopted by way of a 90\% majority of votes cast in the presence of shareholders representing at least half of the share capital (Article 91 item 4 of the Act on Public Offering). Cancelling the dematerialisation of shares means the company loses its public status. 
The withdrawal of shares from public trading takes place in the following stages:

1) Submitting a request, pursuant to the procedure laid down in Article $400 \S$ 1 of the Commercial Companies Code of 15 September 2000 (Journal of Law of 2019, item 505, as amended).

2) Passing a resolution by the general shareholders meeting on the cancellation of dematerialisation of shares.

3) Announcing a tender offer to acquire shares from all other shareholders (the so-called delisting offer).

Regulations regarding tender offers have been implemented from the Directive 2004/25/EC of the European Parliament and of the Council of 21 April 2004 (O.J. L 142/12 of 30 April 2004). The goal of this Directive was to create unified regulations to protect the interests of minority shareholders in the event of the takeover of a public company (Mataczyński, 2010). The European legislator assumes that in the event of delisting a company, the minority shareholders should have a guaranteed possibility of "exiting" the company at a fair price, equal to all interested parties (Regucki, 2012). The regulations related to the obligation of announcing a tender offer were also the subject of discussion on the Polish capital market (Domański \& Goszczyk, 2008; Regucki, 2013).

A tender offer specifies, among other stipulations, a recommended price at which the shares would be purchased from the current shareholders. According to the provisions of the Act on Public Offering, any entity which has gained the control or intends to acquire control over a company through purchasing a considerable block of shares, must publicly announce a tender offer for the sale or exchange of the shares. The Act on Public Offering specifies the rules related to the share price in a tender offer, which cannot be lower than the average market price from the six months preceding the announcement of the tender offer, or the highest price paid for company shares by the entity obliged to announce the tender offer within the preceding 12 months (Article 79 item 1-3 of the Act on Public Offering). If the price cannot be determined based on the above-mentioned criteria, the price in the tender offer should not be lower than the fair value of shares. Furthermore, entities which announce the tender offer pursuant to Article 91 item 6 of the Act on Public Offering are obliged to take into account the fair price of shares in such an announcement. The price offered should correspond to the real value of the shares and not to the value resulting from average stock quotations on the WSE.

Article 28 item 6 of the Accounting Act defines fair value as the amount for which an asset could be exchanged, and a liability settled on the terms of market transactions between knowledgeable, unrelated parties (Journal of Laws of 2019, item 351 - Accounting Act of 29 September 1994). 


\section{Research problem}

The above-presented considerations led to the determination of a research problem, namely, what is the rate of return on the dematerialised shares of companies delisted from the regulated market for their shareholders who have held the securities since the debut of a company on the WSE?

The increase in value of financial instruments over time is an assumption of the classic, long-term "buy and hold" strategy (Choudhry, 2001). Withdrawing a company from public trading results in a shortening of the duration of investment, which might influence the overall results of the investment. Based on this, a research hypothesis has been formulated: investors who have held shares of companies acquired during the IPO achieved a positive rate of return as a result of the delisting of the company from the WSE through the cancellation of the dematerialisation of shares.

The topic of delisting has been a subject of empirical studies on many occasions in the past (Chaplinsky \& Ramchand, 2012; Pour \& Lasfer, 2013; Sanger \& Peterson, 1990). The current studies in the Polish literature have referred only to the value of the control premium in the public tender offers on the Polish capital market (Asyngier, 2017; Bem \& Bącal, 2014) and an analysis of the impact of announced tender offers on the prices of public company's shares (Kabaciński, 2013; Kowalewski, 2006; Szyszka, 2002). So far, no research has been conducted that has focused on the relationship between the price of the tender offer and the price of the IPO. The above-mentioned relationship is worth examining as the regulations guarantee a fair value of shares, although they do not take into account the original issue price. For this purpose, this paper analyses the rate of return and the time which has elapsed between the IPO and the delisting of the company from the WSE as a result of the cancellation of the dematerialisation of shares.

\section{Research methods}

The analysis covers public tender offers announced between 2012 and 2018 on the regulated market of the WSE. In addition to an analysis of literature and legal acts, the research material in this paper includes a method of observation, analysis of source materials and a method of deduction. The paper utilises the data from stock exchange yearbooks and the websites of issuers. The author has compared the IPO price with the price in the tender offer leading to delisting of a company from public trading as a result of the cancellation of the dematerialisation of shares, in order to determine a rate of return for shareholders. In the next step, the author analysed the average time from a company's debut on the WSE to its delisting. Furthermore, the reasons behind the delisting of a company from the public market have been verified. A listed company must meet numerous information obligations, and, above all, must be transparent, which may contribute to making a decision about leaving the stock 
exchange (Nawrot, 2008). For this purpose, all 213 tender offers completed in Poland between 2012 and 2018 have been analysed. The analysis excluded the cases in which companies bought back their own shares. Thus, the final sample group includes 55 tender offers which ended with the delisting of a company from the regulated market of the WSE as a result of the cancellation of the dematerialisation of their shares.

\section{Results and discussion}

In the case of the 35 companies within the sample group, the price in the tender offer was below the IPO price, and for 23 of them, the losses for shareholders who acquired securities during the company's debut on the stock exchange exceeded $50 \%$ (Figure 2). On the other hand, 20 companies generated profit for shareholders who have held the company shares since their debut on the regulated market of WSE, whereas for investors holding securities of 11 companies the share price in the tender offer was more than double the price in the IPO.

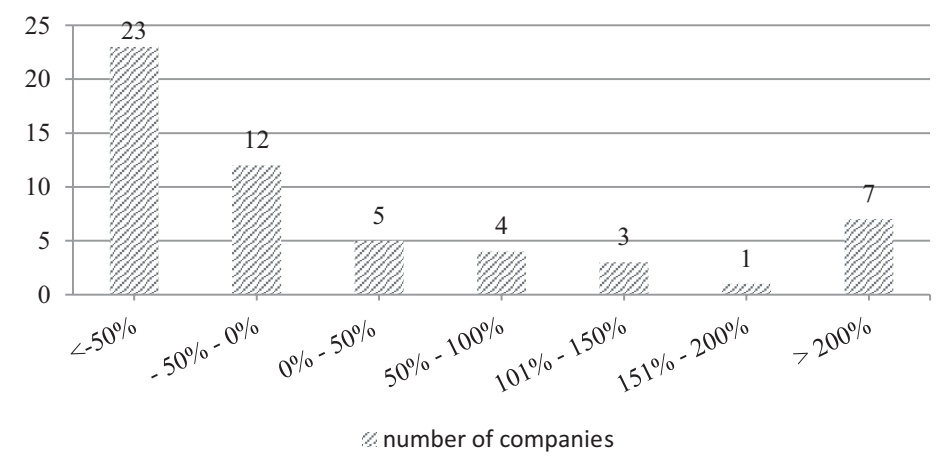

Figure 2. Rate of return for shareholders achieved as a result of the tender offer vs. IPO price

Source: Author's own study based on the data of public companies.

The following companies ensured the highest rate of return for shareholders as a result of the tender offer: Centrum Klima, Graal, Uniwheels, Farmacol, Zelmer, Mondi Świecie, Interger.pl, WDX, Paged, Bank BPH and TU Europa. Public companies which had been withdrawn from the public trading at the stock exchange as a result of a delisting offer and which generated for their shareholders - who have held their shares since their debut on the regulated market of WSE - a loss exceeding $50 \%$ of the IPO price are Midas (previously NFI Kwiatkowski), NFI Empik Media \& Fashion, Hutmen, Rovese (previously Opoczno, Cersanit), Polaqua, Colian Holdings (previously ZPC Jutrzenka), TelForceOne, Synthos (previously Dwory), Barlinek, Mispol, Travelplanet.pl, Elstaroil, Infovide Matrix SA, FAM, Yawal, Avia Solutions Group AB, Wistl, eCard, Olympic Entertainment Group AS, Bakalland, Grupa Duon, 
InPost and Pollena-Ewa. In many cases, the price in the tender offer was at a level that was close to the share price's historic low, while at the same time the company met the obligations resulting from the Act on Public Offering, i.e., the price was not lower than the average price in the preceding six months.

The second stage of the research focused on determining how long a given company was listed on the WSE, i.e., the period from the company's debut until its delisting due to the cancellation of dematerialisation of shares as a result of the tender offer. The arithmetic mean for the analysed companies is 11.5 years, whereas the median period is ten years. Colian Holdings was listed for the longest period of time (23 years), whereas InPost spent the least amount of time at the stock exchange - only two years. A total of $40 \%$ of the companies excluded from trading as a result of delisting offers were listed for a period of between six and ten years, whereas only $5.45 \%$, were listed for more than 21 years.

The share of companies which functioned on the regulated market for the shortest period of time, i.e., from one to five years was $12.73 \%$ (Figure 3 ). A correlation coefficient indicating the correlation between the period of the listing of a company on the WSE and the rate of return for shareholders amounts to 0.12 . This means that there is a small correlation between these data.

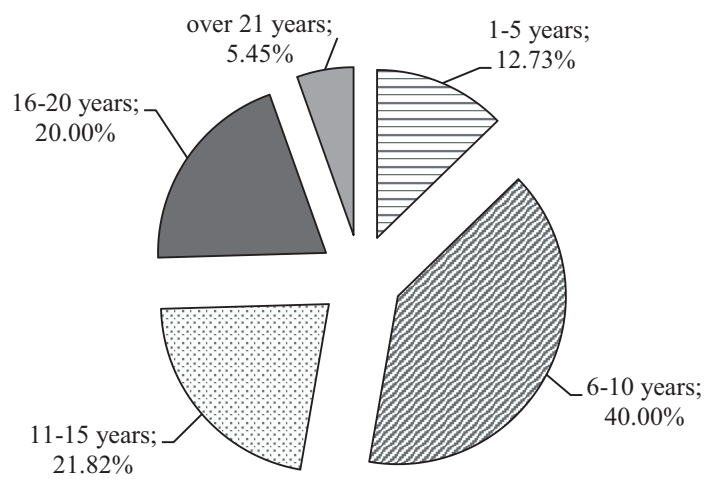

Figure 3. Share of companies excluded from trading between 2012 and 2018 as a result of delisting offers according to the time of functioning on the regulated market of the WSE

Source: Author's own study based on the data of public companies.

The final stage of the research covers the reasons for delisting companies from trading on the regulated market of the WSE between 2012 and 2018.

The cancellation of the dematerialisation of shares made up a $50 \%$ share of the reasons for the exclusion of companies from trading on the WSE's regulated market between 2012 and 2018 (Table 1). This trend has varied over the years, reaching a high of 25 delistings in 2018 , out of which $64 \%$ of companies were excluded due to delisting offers, the goal of which was to cancel the dematerialisation of shares. Several cases of delisting were related to the bankruptcy of companies, their ex- 
clusion at the request of the Financial Supervision Authority (FSA) or to mergers. After withdrawal from the stock exchange, a company loses its public status and is no longer bound by obligations to reveal information about its financial and non-financial data. The supervision of the FSA is also limited. The companies announce tender offers in order to exclude them from trading on the WSE as a result of the dematerialisation of shares because of the reporting requirements, and, above all, because of the consequences of failure to meet such requirements. These obligations result, among others, from the MAR Regulation (Regulation (EU) No. 596/2014...). The low valuation of companies is another reason for the growing number of announced offers of tender.

Table 1. Reasons for delisting companies from trading on the WSE's regulated market between 2012 and 2018

\begin{tabular}{|l|c|c|c|c|c|c|c|}
\hline \multicolumn{1}{|c|}{ Reasons for delisting } & 2012 & 2013 & 2014 & 2015 & 2016 & 2017 & 2018 \\
\hline Cancellation of the dematerialisation of shares & 4 & 5 & 3 & 2 & 10 & 15 & 16 \\
\hline Bankruptcy or liquidation & 1 & 4 & 2 & 6 & 2 & 2 & 5 \\
\hline FSA decision regarding permanent exclusion & 0 & 0 & 0 & 0 & 3 & 2 & 2 \\
\hline Merger & 1 & 1 & 1 & 2 & 1 & 0 & 1 \\
\hline At the request of the issuer & 0 & 0 & 1 & 3 & 3 & 1 & 1 \\
\hline $\begin{array}{l}\text { Financial reorganisation of the issuer - cancel- } \\
\text { lation of shares }\end{array}$ & 0 & 1 & 1 & 0 & 0 & 0 & 0 \\
\hline $\begin{array}{l}\text { Reorganisation of the issuer's capital group } \\
\text { (change of registered office) }\end{array}$ & 1 & 0 & 0 & 0 & 0 & 0 & 0 \\
\hline Total delistings & 7 & 11 & 8 & 13 & 19 & 20 & 25 \\
\hline
\end{tabular}

Source: Author's own study based on (Rocznik Giełdowy 1997-2008)

\section{Conclusions}

The goal of this paper was to analyse whether the share price in the completed delisting offers, which ended with the exclusion of a company from trading on the WSE, ensured a positive ROI for shareholders holding shares from the IPO. An analysis of 213 tender offers announced between 2012 and 2018 by the companies listed on the regulated market of the WSE leads to numerous conclusions.

Firstly, 55 tender offers have led to the exclusion of companies from trading on the regulated market of the WSE as a result of the cancellation of dematerialisation of shares. As many as $64 \%$ of the analysed companies have generated losses for shareholders who have held their shares since the company's debut on the stock market. This means that the stated research hypothesis - that the shareholders who have held the shares of companies acquired at the moment of their IPO, as a result of exclusion of the company from trading on WSE through the dematerialisation of shares always achieved a positive rate of return - is rejected.

Secondly, the arithmetic mean of the time of listing at the stock exchange of a company, which had been excluded from trading on the regulated market of the 
WSE as a result of the cancellation of the dematerialisation of shares, is 11.5 years, whereas the median period is ten years. The biggest group of companies -22 entities, $40 \%$ of the sample group - have been listed from six to ten years. The analysis showed a low correlation between the period of listing a company on the regulated market of the WSE and the value of the rate of return for shareholders.

Thirdly, the cancellation of the dematerialisation of shares was the most frequent reason for the exclusion of a company from trading on the WSE. Information obligations related to the status of a public company have the greatest impact on such decisions. This applies both to financial and non-financial obligations.

The source literature does not include many studies comparing the price for a delisting offer to the price at the IPO. Similar analyses may also be conducted for companies excluded from trading on the WSE. Further research should also explain the impact of rates of return on WIG20, mWIG40 and the sWIG80 indexes on decisions made by companies to carry out delisting offers resulting in the exclusion of an entity from trading on the regulated market of the WSE.

\section{References}

Act of 15 September 2000 - the Commercial Companies Code (Journal of Laws of 2019, item 505, as amended).

Act of 29 July 2005 on Trading in Financial Instruments (Journal of Laws of 2005 No. 183, item 1538, as amended).

Act of 29 July 2005 on Public Offering, Conditions. Governing the Introduction of Financial Instruments to Organized Trading and Public Companies (Journal of Laws of 2019, item 623).

Asyngier, R. (2017). Skuteczność wezwań do sprzedaży akcji na polskim rynku kapitałowym. Annales Universitatis Mariae Curie-Skłodowska, Sectio H - Oeconomia, LI(1).

Bem, J., \& Bącal, G. (2014). Premia za kontrolę oferowana w publicznych wezwaniach do sprzedaży akcji w latach 2006-2013 dla spółek notowanych na GPW w Warszawie. Zeszyty Naukowe Uniwersytetu Szczecińskiego. Finanse, Rynki Finansowe, Ubezpieczenia, 67, 267-278.

Chaplinsky, S., \& Ramchand, L. (2012). What drives delistings of foreign firms from U.S. exchanges? Journal of International Financial Markets, Institutions and Money, 22(5), 1126-1148. doi:10.1016/j. intfin.2012.06.003

Choudhry, M. (2001). The Bond and Money Markets: Strategy, Trading, Analysis. Oxford: Butterworth Heinemann.

Directive 2004/25/EC of the European Parliament and of the Council of 21 April 2004 on takeover bids (O.J. L 142/12 of 30 April 2004).

Domański, G., \& Goszczyk, M. (2008). Nabycie akcji spółki publicznej - obowiązek ogłaszania wezwań. Przegląd Prawa Handlowego, 4, 4-7.

Kabaciński, B. (2013). Ocena efektów fuzji i przejęć na podstawie analizy nadwyżkowych stóp zwrotu. Zarzadzanie i Finanse, 2(4).

Kowalewski, O. (2006). Wartość dla akcjonariuszy mniejszościowych w procesie wycofania spółek z obrotu giełdowego. Bank i Kredyt, 2.

Mataczyński, M. (2010). Ustawa o ofercie publicznej i warunkach wprowadzania instrumentów finansowych do zorganizowanego systemu obrotu oraz o spółkach publicznych. In: T. Sójka (red.), Komentarz. LEX, komentarz do art. 73 ustawy o ofercie publicznej. Warszawa: Wolters Kluwer. 
Nawrot, W. (2008). Rynek kapitałowy i jego rozwój. Warszawa: CeDeWu.pl Wydawnictwa Fachowe.

Pour, E.K., \& Lasfer, M. (2013). Why do companies delist voluntarily from the stock market? Journal of Banking \& Finance, 37(12), 4850-4860. doi:10.1016/j.jbankfin.2013.08.022

Regucki, T. (2012). O potrzebie zmian regulacji wezwań do zapisywania się na sprzedaż lub zamianę akcji - uwagina podstawie struktury własności polskich spółek giełdowych. Transformacje Prawa Prywatnego, 3.

Regucki, T. (2013). Regulacja wezwań do zapisywania się na sprzedaż lub zamianę akcji a pokrzywdzenie akcjonariuszy mniejszościowych. Zarządzanie i Finanse, 2(6).

Regulation (EU) No. 596/2014 of the European Parliament and of the Council of 16 April 2014 on market abuse and repealing Directive 2003/6/EC of the European Parliament and of the Council and Commission Directives 2003/124/EC, 2003/125/EC and 2004/72/EC.

Rocznik Giełdowy. (1997-2008). Giełda Papierów Wartościowych w Warszawie. Retrieved from www. gpw.com.pl

Sanger, G., \& Peterson, J. (1990). An empirical analysis of common stock delistings. Journal of Financial and Quantitative Analysis, 25(2), 261-272. doi:10.2307/2330828

Szyszka, A. (2002). Studium wydarzeń: reakcja inwestorów na publiczne wezwania do sprzedaży akcji. In: D. Zarzecki (red.), Czas na pieniądz. Zarzadzanie finansami: klasyczne zasady - nowoczesne narzędzia, t. 1. Szczecin: Wydawnictwo Naukowe Uniwersytetu Szczecińskiego. 